\title{
Acıgöl Havzası (Denizli) Litolojik Birimlerinin Hidrojeolojik Özellikleri, Yeraltısuyu Seviye ve Debi Haritası
}

\author{
Muhittin KARAMAN $^{1 *}$, Suat TAŞDELEN ${ }^{2}$, Murat BUDAKOĞLU ${ }^{1}$ \\ ${ }^{1}$ İstanbul Teknik Üniversitesi, Maden Fakültesi, Jeoloji Mühendisliği Bölümü, 34469, İstanbul, Türkiye, mkaraman@itu.edu.tr, budak@itu.edu.tr \\ ${ }^{2}$ Pamukkale Üniversitesi, Mühendislik Fakültesi, Jeoloji Mühendisliği Bölümü, Denizli, Türkiye, stasdelen@pau.edu.tr
}

\section{Özet}

Son yıllarda, küresel ölçekte yaşanan yeraltısuyu problemleri nedeniyle, sürdürülebilir yeraltısu kaynaklarının hidrojeolojik özelliklerinin ortaya çıkarılması oldukça önem kazanmıştır. Bu çalışmada, Acıgöl Havzasının litolojik birimlerinin hidrojeolojik özellikleri belirlenerek havzadaki akifer türlerinin karakterizasyonu ve sınıflaması, yeraltısuyu barındıran litolojik birimler, yüksek debili yeraltısuyu barındıran akiferler ve bunların bulundukları konumsal alanlar CBS (Coğrafi Bilgi Sistemleri) ortamında haritalanmıştır. Aynı zamanda, yeraltısuyu seviye haritası üretilerek yeraltısuyu-göl beslenme ilişkisi ortaya konmuştur. Havzadaki allokton, paraotokton ve neootokton litolojik birimler, hidrojeolojik özellikleri ve akifer olabilme potansiyelleri bakımından geçirimli (erime çatlaklı kaya ortam akiferi, taneli ortam akiferi), yarı geçirimli (akitard) ve geçirimsiz (akifüj) ortam olarak ayrımlanmıştır. Oligosen Acıgöl Grubu ve Bodrum Napı birimleri havzadaki gölü besleyen temel akiferlerdir. Marmaris Peridotiti, İğdir Metamorfitleri, Kızılcadağ Melanj ve Olistostromu, Pliyo-Kuvaterner Marn Silt- KilÇamurtaşı ve Çameli Formasyonundaki Çamurtaşı-Marn Üyesi hidrolik iletkenliği olmayan geçirimsiz ortamlardır. Akım yönünün göle doğru olduğu yeraltısuları gölü besler. Acıgöl Fayı ve Maymundağı-Dazkırı Fayı, yüksek debili yeraltısularının bulunduğu ortamlardır.

Keywords: Acıgöl, tuzlu göl, hidrojeoloji, yeraltısuyu seviyesi.

\section{Hydrogeological Features of Lithological Units, Groundwater Level and Flow Rate Map of Acıgöl Basin (Denizli)}

\begin{abstract}
In recent years, due to the groundwater problems experienced on a global scale, it has become very important to reveal the hydrogeological characteristics of sustainable groundwater resources. In this study, the hydrogeological features of the lithological units of the Acıgöl Basin (Denizli) were determined, and the characterization and classification of the aquifers in the basin, the lithological units containing groundwater, aquifers with high flow rate groundwater and their spatial areas were mapped in GIS (Geographic Information System) environment. At the same time, the groundwater-lake recharge relationship was revealed by producing a groundwater level map. Allochthonous, para-autochthonous and neo-autochthonous lithological units in the basin are classified as permeable (fractured rock environment and granular environment), semi-permeable and impermeable environment in terms of their hydrogeological properties and their potential to become aquifers. Oligocene Acıgöl Group and Bodrum Nap units are the main aquifers feeding the lake in the basin. Marmaris Peridotite, İğdir Metamorphites, Kızılcadağ Melange and Olistostrome, Plio-Quaternary Marl Silt-Clay-Mudstone and Mudstone-Marl Member in Çameli Formation are impermeable environments without hydraulic conductivity. The groundwater, where the flow direction is towards the lake, feeds the lake. Acıgöl Fault and Maymundağı-Dazkırı Fault are environments with high-flow underground waters.
\end{abstract}

Keywords: Lake Acıgöl, saline lake, hydrogeology, groundwater level.

\section{Giriş}

Acıgöl havzası gibi tuz ve sodyum sülfat üretimin gerçekleştirildiği endüstriyel göl/sulak alan bulunan havzalarda, yüzey sularının sürdürülebilirliğinin sağlanması amacıyla hidrojeolojik bütçe bileşenlerindeki değişimin denetimi ve kontrolü önemlidir. Sürdürülebilir su kaynakları çalışmalarında yeraltısuyu etkileşimi su bütçesindeki önemli bir bileşendir (Hacısalihoğlu ve Karaer, 2018). Yağış, yüzey akışı, dereler, buharlaşma ve çekilen su miktarı su bütçesine ait diğer bileşenlerdir (Davraz ve Balın, 2015).

Başta insan etkisi olmak üzere iklim koşullarına bağlı olarak yüzey ve yeraltısularında meydana gelen değişim ile sulak alanlar da değiş̧ime uğramaktadır (Çakaröz vd., 2020; Karaman ve Özelkan, 2022).

Kar ve yağmur suyu, gel-git suları, yeraltısuyu, çevre alanlardan yüzey akışı ile gelen sular sulak alan girdisini oluştururken (Marsh, 1991), buharlaşma, terleme, yeraltına

\footnotetext{
* Corresponding author :İstanbul Teknik Üniversitesi, Maden Fakültesi, Jeoloji Mühendisliği Bölümü, 34469, İstanbul, Türkiye, mkaraman@itu.edu.tr
} 
sızma, nehir ve derelerin kolları tarafından dışarı drene edilmesi su çıkışlarını oluşturur (Çağırankaya ve Köylüoğlu, 2013; Korkanç, 2004). Havzalardaki yeraltısuyu beslenimini yağış, yüzeysel akış, komşu akiferler (içe akış), sulamadan dönen sular ve şebeke kayıpları sağlar (Aksever, 2012). Hidrolojik, jeolojik ve meteorolojik koşullar yeraltısuyunu etkileyen doğal faktörler iken kullanım, içme ve tarımsal sulama amaçlı su çekimi de insan kaynaklı faktörlerdir (Y1lmaz, 2010).

Tarımda sulu tarım alanlarının artması ve buna bağlı olarak tarımsal sulama amaçlı aşırı su çekimi, yeraltısularının aşırı kullanımı, artan kuraklıklarla beraber yağışların azalması havzalardaki su tablasında önemli bir düşmeye, hidrolojik dengenin bozulmasına ve bu alanlardaki ekosistemin yok olmasına neden olur (Yılmaz, 2010, Aydın vd., 2013; Çakaröz vd., 2020).

Havzadaki su tablasındaki aşırı düşüş birçok olumsuz sonuçları beraberinde getirir. Yeraltısuyu seviyesindeki alçalmalar, havzadaki bazı akiferlerin özelliklerini kaybetmesine, var olan yüzey sularının kurumasına, toprakta çoraklaşma ve tuzlanmaya neden olabilir (Y1lmaz, 2010).

Yeraltısuyunun aşırı çekimi, tuzlu suyun tatlı su alanlarına doğru ilerlemesine neden olurken, tatlı su kuyuları tuzlu su alanları içinde kalır. Tuzlanan suların kullanımı bitkilerde tuz etkisinin oluşmasına ve tarım alanlarında çoraklaşma problemine neden olur (Essink, 2001; Arslan ve Demir, 2011).

Sıcaklıklar ve buharlaşmadaki aşırı artmaya karşın yağışlardaki önemli azalış şeklinde gerçekleşen iklim koşullarının olumsuz etkilerinin yanında tarımsal sulama ve kullanım amaçlı aşırı insan etkisine bağlı su tüketimi havzada çölleşmeye neden olmaktadır (Özdemir, 2009). Acıgöl Havzasında tarımsal ve kullanım amaçlı yeraltısuyu kullanımının yoğun olmasının yanında doğal ve endüstriyel yolla sodyum sülfat üretilmesi amaciyla gölden su çekiminin yapılması, gölün hidrojeolojik dengesinin korunmasını ve denetimini önemli hale getirmektedir.

Acıgöl Havzasındaki su kaynaklarının sürdürülebilirliğin sağlanmasına altlık olması amacıyla gerçekleştirilen bu çalışmada; i) litolojik birimlerin hidrojeolojik karakteristikleri ve akifer sınıflaması yapılmış, ii)sayısal yükseklik modelinden yararlanılarak havza sınırı ve drenaj ağı elde edilmiş, iii) yeraltısuyu seviye ölçümleri gerçekleştirilerek yeraltısuyu seviye haritası oluşturulmuş ve iv) yeraltısuyu akım yönleri belirlenmiştir. Havzada Devlet Su İşleri (DSİ) tarafından açılan derin sondajlara ait debi verileri kullanılarak havzadaki yeraltısularının debi haritası üretilmiş ve havzadaki yüksek debili yeraltısularının alansal dağılımları belirlenmiştir.

\section{2. Çalıșma alanı, Veri ve Yöntem}

\subsection{Acıgöl Havzası (Denizli)}

Acıgöl Graben Havzası, Güneybatı Anadolu'da DenizliBurdur ve Afyonkarahisar il sınırlarının kesişim bölgesinde yer alır. Sınırları Denizli M-23 ve Isparta M-24 paftalarında yer alan havzada Çardak (Denizli), Dazkırı, Başmakçı ve Evciler (Afyonkarahisar) ilçelerini barındırır (Şekil 1). 38 8'60.00"K - 37³6'25.20"K kuzey enlemleri ve 30॰11'9.60"D - 29³2'24.00"D doğu boylamları arasında kalan havzada, Tuz Gölü'nden sonraki en büyük tuzlu göl niteliğinde ve sodyum sülfat üretiminin gerçekleştirildiği alkali, playa Acıgöl bulunur. Sodyum sülfat üretiminin 1950li yıllara dayandığ havzada, göl kıyısına açılmış yapay havuzlarda doğal yolla ve endüstriyel yöntemlerle üretim gerçekleşir. Havzanın merkezinde yer alan gölün deniz seviyesinden yüksekliği 836 m'dir (Karaman vd., 2015). Havzadaki sodyum sülfat üretimi Türkiye'deki üretimin önemli kısmını oluşturur (Gündoğan vd., 1995).

Havza yarı kurak iklim koşulları etkisi altındadır. Uzun yıllar yıllık toplam yağış ortalaması $385 \mathrm{~mm}$ ve ortalama hava Sıcaklığı $13.4^{\circ} \mathrm{C}$ 'dir. Y1llık su bütçesine göre havzadaki suyun $372 \mathrm{~mm}$ 'si evapotranspirasyon ile atmosfere geri döner. İklim özelliklerine bağlı olarak yağışl1-kurak döngüsünde yüzey suları etkilenir. Havza içindeki en büyük yüzey suyu olan Acıgöl'de yağışli-kurak dönem geçişlerinde göl seviyesi ve buna bağlı olarak gölalanı iyice azalırken, evaporatif konsantrasyona bağlı olarak gölde iyon derişimi de artar. Yağışl1-kurak döngüsünde gölün alansal değişimi \%50'den fazladır (Karaman vd., 2015).

\subsection{Jeolojik Veriler ve İşlenmesi}

Maden Tetkik ve Arama Genel Müdürlüğü'nden (MTA) elde edilen 1/100.000 ölçekli vektör jeoloji haritasının M23 ve M24 paftaları, Acıgöl Havzasında yer alan litolojik birimlerin geçirimlilik durumlarına göre hidrojeolojik özelliklerinin tanımlanmasında ve geçirimlilik haritası oluşturmasında kullanılmıştır.

\subsection{Topografik Veriler ve İşlenmesi}

Acıgöl Havzasına ait sayısal yükseklik modeli (SYM), Harita Genel Komutanlı̆̆ (HGK)'ndan temin edilen 1/25000 ölçekli topografik haritaların $10 \mathrm{~m}$ 'de bir sayısallaştırılmış eşyükselti eğrilerinden ArcGIS ortamında ANUDEM (Australian National University's Digital Elevation Model) algoritmas1 (Hutchinson, 1988; Karaman ve Özelkan, 2022) ile $10 \mathrm{~m}$ mekânsal çözünürlükte üretilmiştir. SYM kullanılarak, havza sınırı, havza drenaj ağı ve akış yönleri, oluşturulmuştur.

\subsection{Sondaj Verileri ve İşlenmesi}

Yeraltısuyu seviye ve debi haritasının oluşturulmasında havzada DSİ tarafından açılmış ve dinamik, statik seviye bilgileri, kimyasal analiz sonuçlarını ve dikme kesit bilgilerini içeren DSİ'den alınmış koordinatlı kuyu logları kullanılmıştır. Kuyu loglarındaki bilgiler önce elektronik sayısal tablolama yazılımında sayısallaştırılmış ve ArcGIS yazılımı ile CBS (Coğrafi Bilgi Sistemleri) ortamına aktarılmıştır. Verilerin alansal dağılımlarının belirlenmesinde mekânsal enterpolasyon yöntemlerinden deterministik yaklaşım ile çalışan ve giriş noktalarından tam olarak geçen bir enterpolasyon sonucu üreten Spline (Franke, 1982) algoritması kullanılmıştır.

\section{Bulgular ve Tartışma}

\subsection{Genel Jeoloji}

KD-GB uzanımlı sismik olarak aktif neotektonik bir graben olan havza genişleme ve çökme mekanizmasıyla gelişmiştir (Toker, 2008). KD-GB yönlü faylarla sınırlandırılan havzanın kuzeyini Maymundağı-Dazkırı Fayı, güneyini ise Acıgöl fayı sınırlar. Maymundağı-Dazkırı Fayı Paleojen ve Neojen birimleri keserken, güneydeki Acıgöl Fayı Kuvaterner birimleri keser (Helvaci ve diğ. 2013; Kazanc1 ve diğ. 2006; Şenel 1997a; Temiz ve diğ. 1997; Toker 2008). 


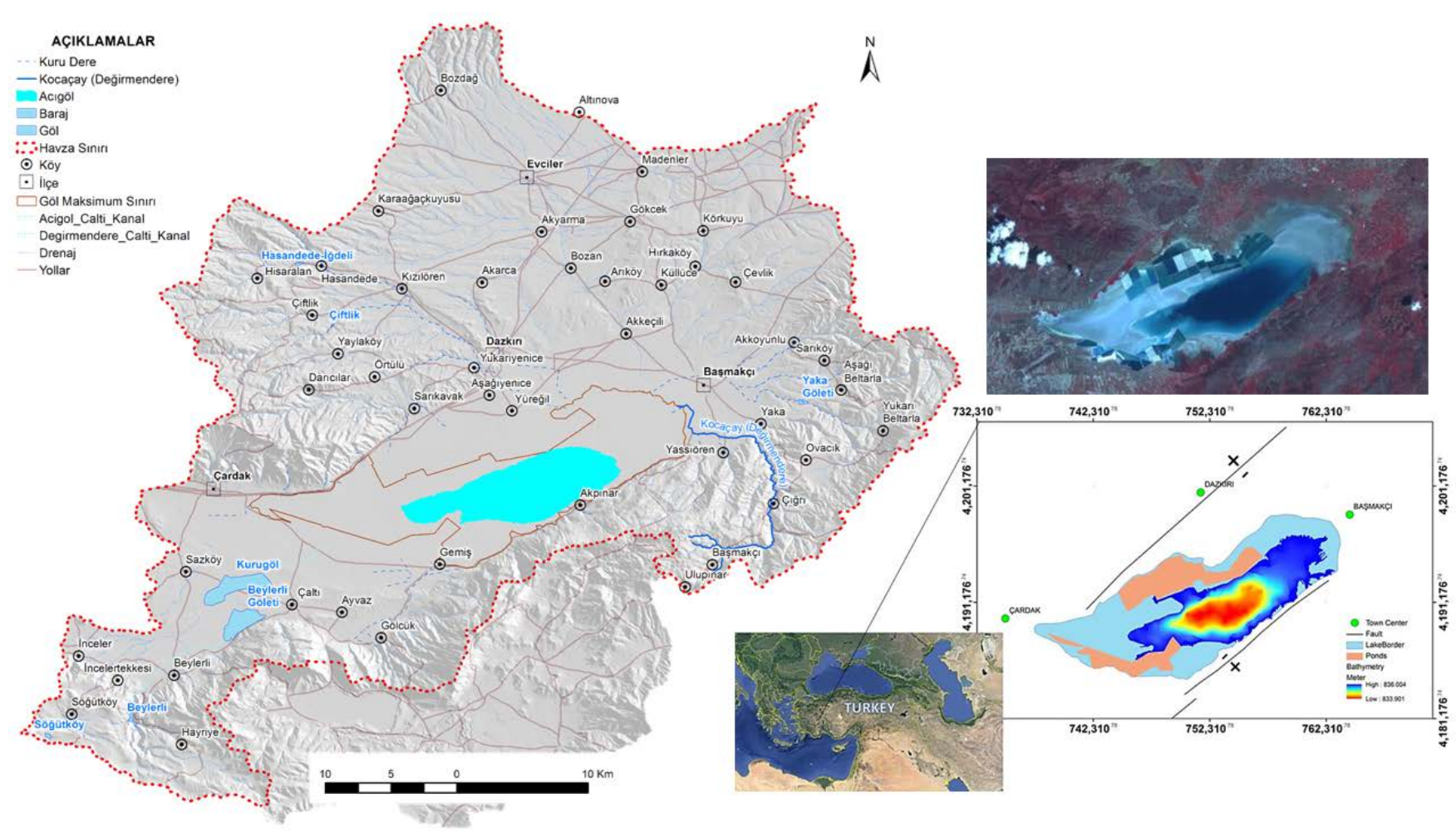

Şekil 1 Acıgöl Havzası.

Havza, Likya Torosları'nda Likya orojenezi sırasında nap yerleşiminin en son evresinde karasal havzaların çökmesiyle oluşmuştur (Alçiçek 2009; Alçiçek 2007; Alçiçek ve diğ. 2006; Collins ve Robertson 1999; Helvaci ve diğ. 2013; Kazancı ve diğ. 2006; Seyitoğlu ve Scott 1996; Toker 2008).

Havza KB-GD yönlü genișleme tektoniği altındadır. Havzada genişleme tektoniği birbirini kesen KB-GD ve KDGB doğrultulu iki yönlü fay sistemleri etkisindedir (Temiz ve diğ. 1997; Toker 2008).

Havzanın jeolojisini yaşlıdan gence doğru allokton olarak yerleşmiş Likya napları ile paraotokton ve neootokton konumlu litolojik birimler oluşturur. Havzada Likya napları Tavas napı, Bodrum nap1, Marmaris ofiyolit nap1, Gülbahar napı ve Domuzdağ napı ile temsil edilirken, Üst Paleosen yaşlı Mamatlar Formasyonu, Eosen yaşlı Varsakyayla Formasyonu, Oligosen yaşlı Acıgöl grubu ve Alt Miyosen yaşlı Kavak Formasyonu paraotokton birimleri temsil eder. Neootokton birimler de Tortoniyen yaşlı molas karakterindeki Aksu Formasyonu, gölsel Pliyosen ve karasal Kuvaterner örtü birimleri ile temsil edilir (Şenel 1997a, 1997b) (Şekil 2).

Havzada çok küçük bir alanda temsil edilen Tavas napına ait birim Uluborlu Formasyonunun İncesu Konglomera üyesidir (Tpeui). Tavas napı üzerinde tektonik dokanakla gelen Bodrum napını yine tektonik olarak Marmaris ofiyolit nap1 üzerler. Marmaris ofiyolit napını da Gülbahar ve Domuzdağ napları üzerler. Bodrum nap1, havzanın güneyinde Kayaköy Dolomiti, Yandağ Formasyonu ve Karabögürtlen Formasyonu ile temsil edilir. Marmaris ofiyolit napı, Marmaris peridotiti, peridotit içinde tektonik dilimler halinde bulunan İğdir Metamorfitleri ve Kızılcadağ Melanj ve Olistostromu ile temsil edilir. Jura-Kretase yaşlı Orhaniye Formasyonu Gülbahar napını temsil ederken, Likya naplarının en üstünde yeralan Domuzdağ 1 havzada Dutdere Kiraçtaşı ile temsil edilir (TRJd) (Şenel 1997a, 1997b) (Şekil 2).
Allokton Mesozoyik karbonatlı birimler ile ofiyolitik melanj, ofiyolitler havzanın güneyindeki, Oligosen yaşlı denizel tortul birimler de havzanın kuzeyindeki birimlerin temelini oluşturur (Alçiçek 2009; Helvaci ve diğ. 2013; Şenel 1997a; Toker 2008; Toker ve diğ. 2012) (Şekil 2).

Kayaköy Dolimiti, $\left(\mathrm{T}_{\mathrm{R}} \mathrm{Jk}\right)$, dolomit ve dolomitik kireçtaşlarından oluşan birim sı̆̆ karbonat şelf ortamında çökelmiştir. Havzanın güneyinde Gemiş ve Gölcük civarında görülen birim, ikincil olarak gelişen kalsit dolgularının yaygın olduğu oldukça kırıklı çatlaklı yapılı ve sık erime boşlukludur. Orta-Geç Triyas-Orta Liyas yaşlı birim, genelde homojen doku ve tabaka yapısına sahiptir (Şenel 1997a, 1997b).

Yandağ Kireçtaşı (JKya), havzanın güneyinde geniş bir alanda mostra veren Jura-Kretase yaşlı birim, tabanında neritik kireçtaşları, üste doğru çörtlü kireçtaşı, radyolarit-çört ve mikritik kireçtaşları ile temsil edilir. Birim altta az kristalize, dolgusu kalsit olan bol çatlaklıdır. Birimin, kireçtaşı oranının iyice azaldığı ve tamamıyla radyolarit ve çörtlerin hakim olduğu üst kısımlarında eklem ve çatlaklar tamamıyla kalsit dolgusundan oluşur. Çörtlerin üzerinde mikritik kireçtaşları bulunur (Bilgin ve diğ. 1990; Şenel 1997a).

Karaböğürtlen Formasyonu (Kka), Geç Senoniyen yaşlı (Sarp, 1976) olup havzada İğdir Köyü ve Aşağıkırlı Köyü civarında yaygın olarak mostra veren birim havzanın güneyinde doğu-batı uzanımlı bir hat boyunca görülür. Tabakalı kumtaşı, kiltaşı ve silttaşlarından oluşan birimin bazı kısımlarında serpantinit, bazik volkanit ve kireçtaşı blokları yer alır (Şenel 1997a).

Marmaris Peridotiti (Kmo), yer yer serpantinleşmiş ultramafik kayalardan oluşur. Alt Kretase (Apsiyen-Albiyen) yaşlı birimde, harzburjit ve yer yer harzburjitlerle ardalanan dünitler görülür. Olivin ve piroksen kristallerinin görüldüğü birimde, serpantinleşmenin olduğu kısımlarda parlak renkli kristaller matlaşmıştır. Piroksenlerin lizarditleşmesi, kayaç yüzeyindedir. Tektonizma ortamlarında serpantinitlerin yoğun 
olduğu birimde gabro, diyabaz, piroksenit vb. kaya türleri

görülür (Şenel 1997a).

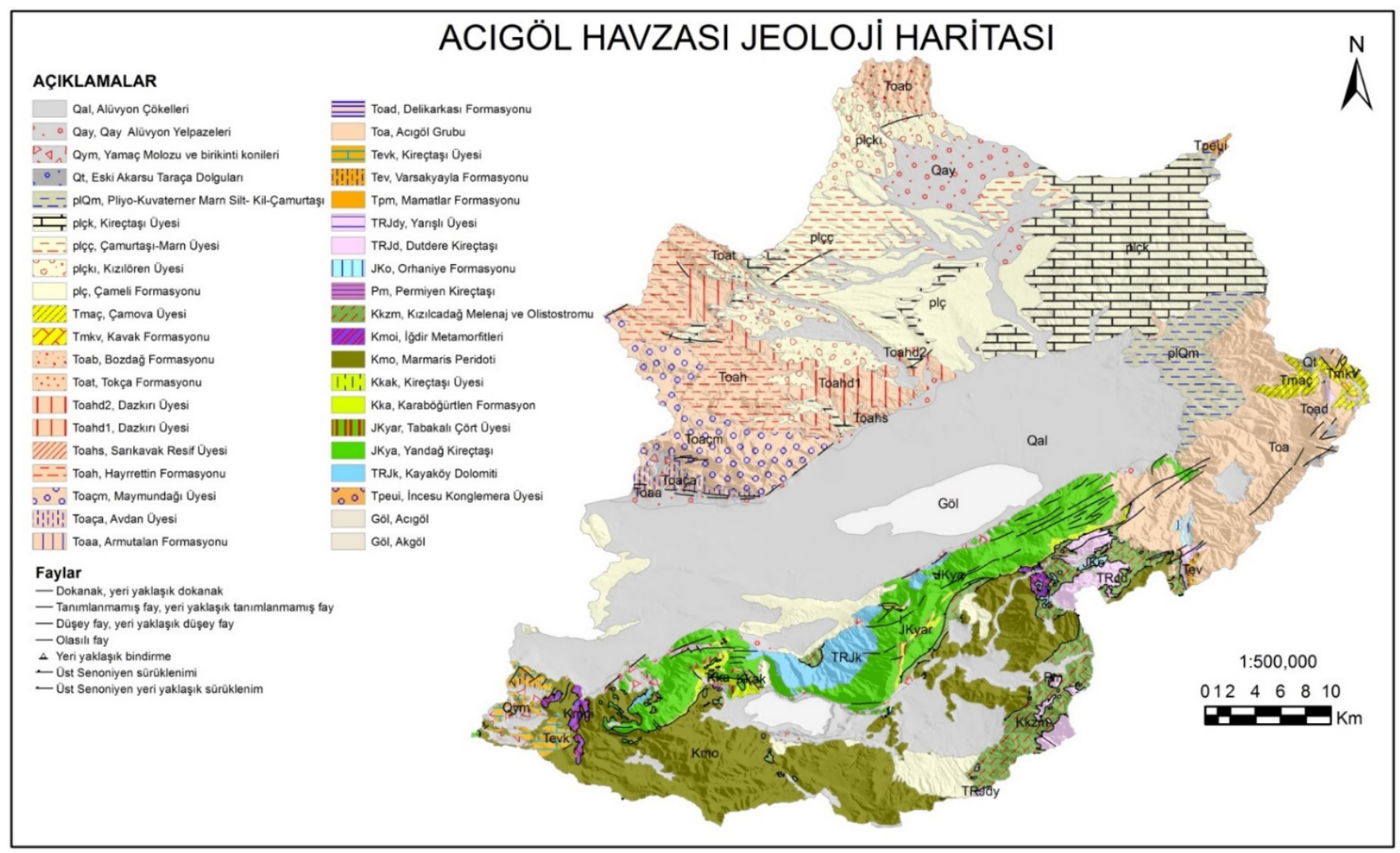

Şekil 2 Acıgöl Havzası genel jeoloji haritası (Balci (1987); Göktaş ve diğ. (1989); Şenel (1997a, 1997b)'dan güncellenmiştir).

İğdir Metamorfitleri (Kmoi), Marmaris peridotiti tabanındaki birim, volkano-sedimanter kayaçların metamorfizmasıyla oluşmuştur. Amfibolit, amfibol gnays, amfibol-şist, kuvarsit, metabazalt, metaçört, bantlı mermer ve mermerlerden oluşur. Havzada İğdir ve İncelertekkesi Köyü civarında görülür (Bilgin ve diğ. 1990; Şenel 1997a).

Kızılcadağ Melanj ve Olistostromu (Kkzm), havzanın güneyinde Gölcük Köyü civarında ve Alanköy'ün kuzey doğusunda, Aşağıkırlı Köyü civarında, İğdir Köyü’nün doğusunda ve Elden ve Ulupınar köylerinde görülür. Üst Senoniyen yaşlı olan birim serpantinit, serpantinleşmiş harzburjit, dünit vb. kaya türlerinden oluşur. Egemen olarak blokları ofiyolit olan birimde radyolarit, çört, dolomit, neritik ve pelajik kireçtaşı, diyabaz, serpantinit, peridotit, gabro, bazik volkanit blokları yer alır (Poisson 1977; Sarp 1976; Şenel 1997a; Şentürk 2003).

Orhaniye Formasyonu (JKo), havzada Ulupınar, Başmakçı, Elden ve Çığrı Köyü civarında görülür. Türbiditik kireçtaşları, pelajik kireçtaşları, çört ve radyolarit içeren birim Jura-Kretase yaşlıdır (Meşhur ve diğ. 1989; Şenel 1997a; Şenel ve diğ. 1989).

Dutdere Kireçtaşı (TRJd), Orta-Triyas yaşı olup rekristalize kireçtaşlarından oluşur (Ersoy 1989, 1990; Şenel 1997a; Şenel ve diğ. 1989). Havzada Ulupınar, Başmakçı ve Çı̆̆rı Köyü arasında görülür.

Geç Paleosen yaşılı Mamatlar Formasyonu (Tpm) algli kireçtaşlarından oluşur ve tabanını polijenik konglomera ve kumtaş1 oluşturur (Şenel 1997b).

Eosen yaşlı Varsakyayla Formasyonu (Tev), havzanın güneybatısında İnceler Köyü'nün güneyinde ve Söğüt Köyü etrafında görülür. Kiraçtaşı ve kırıntılı kayalardan oluşan birimin tabanında konglomera ve üzerinde kiraçtaşı üyesi, onun üzerinde de kumtaşı, silttaşı ve kiltaşı yer alır (Bilgin ve diğ. 1990; Şenel 1997a).

Havzadaki Oligosen yaşlı Acıgöl grubuna (Toa) ait birimler, Armutalan Formasyonu, Çardak Formasyonu, Hayrettin Formasyonu, Tokça Formasyonu, Bozdağ Formasyonu ve Delikarkası Formasyonudur (Bilgin ve diğ. 1990; Şenel 1997a). Acıgöl Grubu, masif ve kalın tabakalı çakıl-kumtaşı ve masif çamur taşından meydana gelir (Koralay 2014). Acıgöl Grubuna ait birimler havzanın kuzeybatı ve güneydoğusunda önemli yayılıma sahiptir. Alt Miyosen yaşlı Kavak formasyonu (Tmkv), kumlu kireçtaşı karakterindedir.

Havzadaki Miyosen birimler, kalın konglomeralardan oluşan Aksu Formasyonu, Pliyosen birimler konglomera, kumtaşı, çamur taşları ve gölsel çökellerle (kiltaşı, silttaşı, marn, killi kireçtaşı ve az oranda kumtaşı, konglomera, traverten vb.) temsil edilen Çameli Formasyonudur. Çameli Formasyonu içinde killi kireçtaşı ve manyezitli dolomit seviyeleri de görülür (Bilgin ve diğg. 1990; Şenel 1997a).

Kuvaterner Örtü Birimleri, eski akarsu taraça dolguları (Qt), yamaç molozu birikinti ve konileri (Qym), alüvyon yelpazeleri (Qay), alüvyon çökellerinden (Qal) oluşur. Havzanın kenarını kaba kırıntılı kalüvyal ve alüvyal tortullar, merkezini Kuvaterner yaşlı gölsel tortullar oluşturur (Şenel 1997a). Gölalanı içinde kadar sokulan yamaç molozu akıntıları yaygındır. Gölün güneyinde kaynak kayaların özelliğini yansıtan yelpaze deltaları gölün güneyinde fay düzlemi boyunca gelişmiştir. Alüvyon çökelleri, iyi tutturulmamış, kaba kırıntılı çakıl, kum ve silt birikintileri şeklinde gölün çevresinde, akarsu yataklarında ve taşkın düzlüklerinde bulunur (Şenel 1997a). 


\subsection{Drenaj Alanı}

Drenaj sistemine göre havza hidrolojik olarak kapalı bir sisteme sahiptir. Drenaj sistemi tüm yüzey akışını göle doğru taşır. Havzada buharlaşma ve sodyum sülfat üretimi dişında yüzey boşalımı bulunmaz. Tuzlu Acıgöl'ün de içinde bulunduğu havzanın drenaj alanı 1594 km²'dir (Şekil 3). Havza içerisinde sürekli bir yağışl1-kurak dönem döngüsünde hacmi ve alanı değişen tuzlu Acıgöl ile birlikte, Beylerli Gölü ve Kurugöl (Çaltı Gölü) bulunur. Havzaya önemli su girişlerinden biri olan Değirmendere üzerine Hambat Ovası'ndaki tarımsal alanları sulama amaçlı inşa edilmiş Beylerli Barajı bir diğer önemli yüzey suyudur. Bunun dışında Sarıkavak, Çiftlik, Sögüt, Hisaralan, Kanlıca (İnceler), Yaka göletleri de havza drenajı içindeki diğer küçük sulardır. Başmakçı Çat Suyu'ndan başlayarak Acıgöl'e ulaşan Kocaçay ile birlikte Beylerli Barajı'nı besleyen Değirmendere ve havzanın kuzeyinde sadece yağışlı dönemde akar halde olan Çiftlik Köyü yakınlarında Çarşak Dere ve Hisaralan Köyü yakınlarında İğdeli Dere bulunur.

Yüzey suyu akım uzunluğu havzanın kuzeyinde oldukça fazla iken güneyinde oldukça kısa mesafelidir. Gölün güneyinde yüksek eğim ve düşük akım uzunluğu nedeni ile yağışlar gölü beslerken, kuzeydeki yüksek akım uzunluğu nedeni ile normal yağışlar yeraltısuyunu besler. Havzanın kuzeyindeki drenaj, yoğun ani (yüksek miktarlı) yağışları göle taşır.

\subsection{Kayaçların Hidrojeolojik Özellikleri}

Havzadaki temel akiferler, Pliyosen Çameli Formasyonunun altında kalan Oligosen Acıgöl Grubu ve karstik yapılı ve bol çatlaklı Bodrum Napı birimlerinden oluşur. Oligosen Acıgöl Grubu ve Bodrum Napı birimleri, gölü besleyen akiferlerdir. Akifer niteliğinde olan Orhaniye Formasyonu, Dutdere Kireçtaşları ve Varsakyayla Formasyonu doğrudan gölü beslemezler. Gölün güneyindeki Bodrum Napı birimlerindeki karstik akiferin yeraltısuyu, göl kenarındaki fay düzlemi boyunca yüzeylenerek gölü besler. Havzanın GB'sında Beylerli civarında örtü kayasını Çameli Formasyonu (plç) ve hazne kayasını Yandağ Kireçtaşının (TRJk) oluşturduğu jeotermal sistem gelişmiştir. Jeotermal sistemin gelişmesinde graben havzasının güneyindeki KD-GB aktif faylar nedeniyle, kabuğun bu bölgede incelmiş olması etkindir (Akın 2012). Hidrojeolojik özellikleri dikkate alınarak havza içerisindeki jeolojik birimler, Erime Çatlaklı Kaya Ortam Akiferi, Taneli Ortam Akiferi, Akitard Ortam (Yarı Geçirimli) ve Akifüj (Geçirimsiz) Ortam olarak ayrımlanır (Şekil 4).

\subsubsection{Erime Çatlaklı Kaya Ortam Akiferi}

Yüksek derecede ikincil gözeneklilik ve geçirgenliğe sahip olmaları nedeniyle Kayaköy Dolomiti ile Yandağ Kireçtaşı gölü besleyen iyi bir akifer niteliğindedir. Kayaköy Dolomiti, bol eklem yapılı ve eklem dolgusunu kalsitin oluşturduğu sık erime boşluklu dolomitik kireçtaşlarından oluşur. Eklem çatlaklarının tamamen kalsitle dolu olduğu ve mikritik kireçtaşları ile temsil edilen Yandağ Kireçtaşı ise tabanda neritik, üste doğru çörtlü seviyeler barındırır. Çatlak sistemleri ve erime boşlukları vasıtasıyla önemli miktarda yeraltısuyunun depolandığı ve aynı zamanda iletildiği ortamlardir.

Gölün güneyinde erime çatlaklı kaya ortam akiferinden boşalan sürekli kaynaklar, doğrudan gölü beslerler. Çörtlü mikritlerden oluşan Orhaniye Formasyonu, Varsakyayla Formasyonu içindeki ofiyolit kırıntılı kireçtaşlarının yer aldığı Kireçtaşı Üyesi, rekristalize taşlarından oluşan Dutdere Kireçtaşı, kumlu kireçtaşı karakterindeki Kavak Formasyonu, mercanlı resifal kireçtaşından oluşan Acıgöl Grubu Sarıkavak Resif Üyesi ve bol nummulitli kireçtaşlarından oluşan Delikarkası Formasyonu da diğer erimeli çatlaklı kaya ortam akiferleridir.

\subsubsection{Taneli Ortam (yaygın verimli)Akiferi}

Havzadaki taneli ortam akiferlerini Kuvaterner örtü birimleri olan sırasıyla alüvyon çökelleri, alüvyon yelpazeleri, eski akarsu taraçaları, yamaç molozu ve birikinti konileri oluşturur.

\subsubsection{Akitard (Yarı Geçirimli) Ortam}

Havzadaki en önemli akitard ortam Acıgöl Grubu'dur. Masif ve kalın tabakalı çakıl-kumtaşı ve masif çamur taşından meydana gelen akitard ortam Armutalan Formasyonu, Bozdağ Formasyonu, Avdan Üyesi, Maymundağı Üyesi, Hayrettin Formasyonu ve Dazkırı Üyesi ile temsil edilir. Havzadaki diğer akitard ortamlar ise Çameli Formasyonu Kızılören Üyesi ve Karaböğürtlen Formasyonudur. Yarı geçirimli birimlerdeki kumtaş1, çakı1ltaş1, çamurtaşı, konglomera ve kireçtaşı seviyeleri düşük hidrolik iletkenlikle beraber yeraltısuyu potansiyeline sahiptir.

\subsubsection{Akifüj (Geçirimsiz) Ortam}

Havzadaki hidrolik iletkenliği olmayan geçirimsiz birimler Marmaris Peridotiti, İğdir Metamorfitleri, Kızılcadağ Melanj ve Olistostromu, Pliyo-Kuvaterner Marn Silt-Kil Çamurtaşı ve Çameli Formasyonundaki Çamurtaşı-Marn Üyesi'dir.

\subsection{Acıgöl Havzasında Yeraltısuyu Hareketi}

Havza içinde farklı dönemlerde DSİ tarafından açılmış sondaj sayısı 200'ün üzerindedir (Şekil 5). Bunun dışında kayıt altında olmayan havza içinde tarımsal sulama ve kullanım amaçlı açılmış özel sı̆̆ sondajlar da bulunur.

Havza içinde DSİ tarafından açılan kuyuların statik ve dinamik seviye ölçümleri işletmeye alınmadan önce bir defaya mahsus yapılmakta sonraki dönemlerde ölçüm gerçekleştirilmemektedir. Havzanın tümünde, tüm sondajları kapsayacak şekilde su seviyelerinin eş zamanlı (yağışl1-kurak dönem geçişinde seviye farklılığının olabileceği gözetilerek) periyodik ölçümü ve tüm havzada ölçülmüş eş zamanlı verilerden elde edilen yeraltısuyu seviye haritası bulunmamaktadır. Havza içinde DSİ tarafindan açılan sondajların işletimi farklı sulama birliklerine devredilmiştir. Havzada üretilen tarımsal ürünlerin çeşitliliğine bağlı bölgesel farklı sulama dönemleri nedeniyle yönetimleri farklı sulama birliklerinin organize edildiği eş zamanlı su seviye ölçümleri gerçekleştirilememiştir. Havzanın yeraltısuyu seviye ve akım yönü haritasını üretmek için yeterli sayıda DSİ sondajı bulunsa da eş zamanlı ölçümün gerçekleştirilememesi ve seviye ölçümlerinin sadece açıldığı yılları temsil etmesi ve veri bütünlüğünün oluşmadığı gerekçeleri ile havza için genel seviye haritası ve yeraltısuyu akım yönü haritası üretilememiştir. 


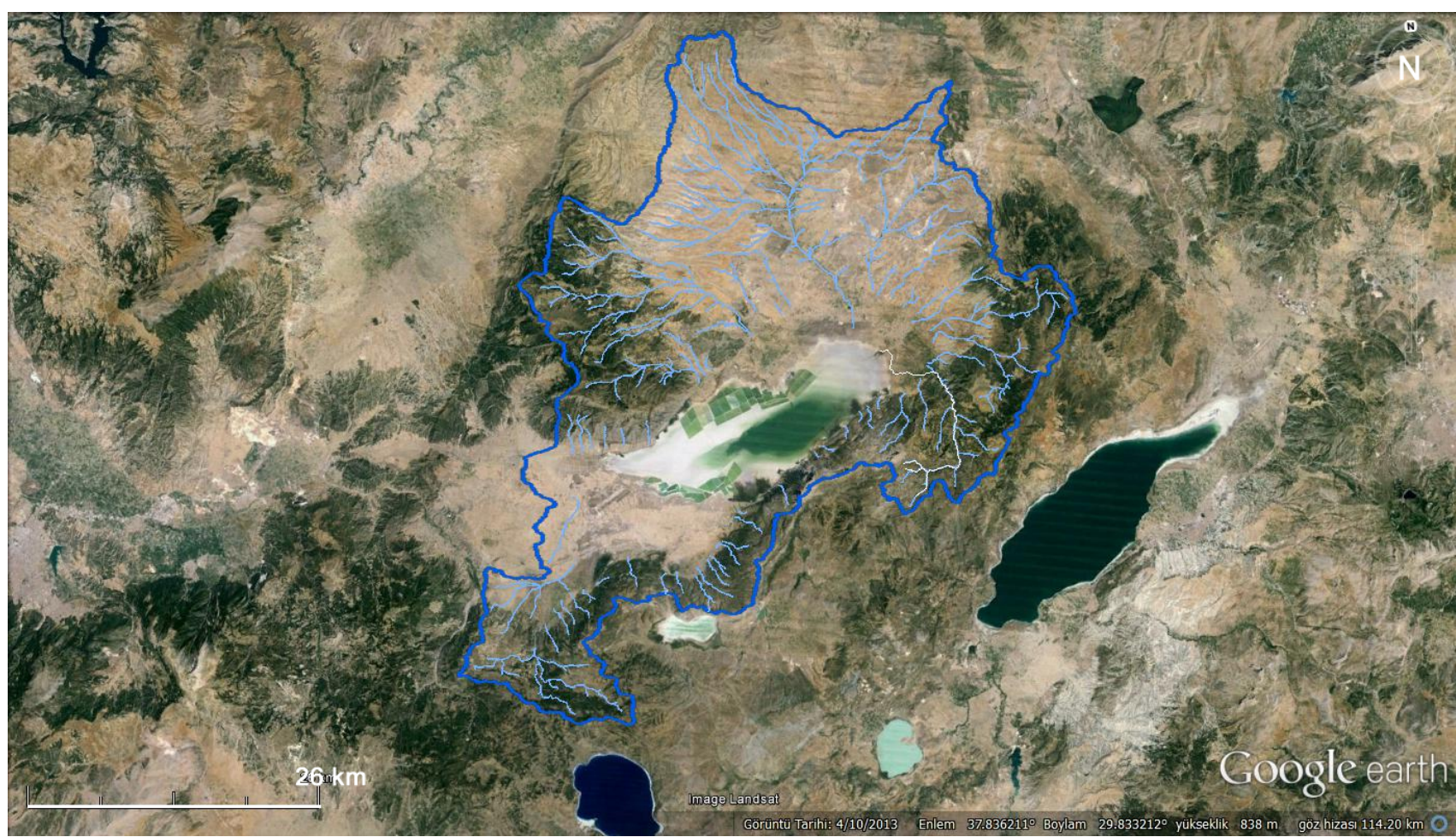

Şekil 3 Acıgöl Havzası drenaj alanı $(1594$ km²).

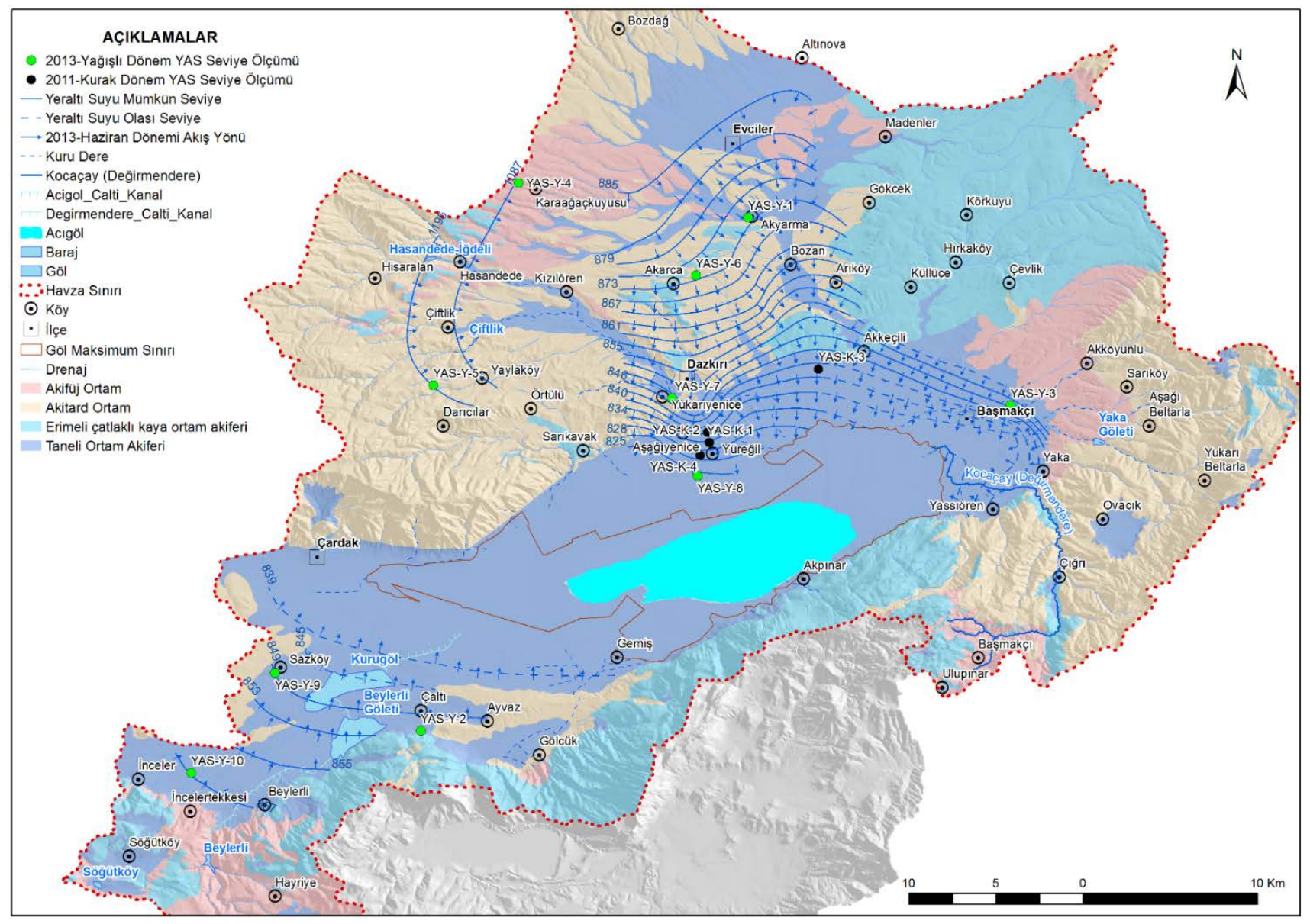

Şekil 4 Acıgöl Havzası hidrojeoloji haritası.

Havzanın farklı bölgelerinde yeraltısuyu akım yönünün belirlenmesinde kullanılabilecek ilgili farklı sulama birliklerindeki bazı sondajlarda yağış̧l-kurak dönem seviye ölçümleri yapılmıştır. Çalışma kapsamında seviye ölçümünün yapıldığı sondajların birkaç gün önceden kullanımının durdurulmuş olmasına dikkat edilmiştir. Ölçümün yapıldığ 1 sondajların bulunduğu bölgeler için yeraltısuyu seviye haritası ve yeraltısuyu akım yönü belirlenmiştir. Ölçümler 2013 su yılı kurak ve yağış̧l döneminde gerçekleştirildiğinden yeraltısuyu seviye haritası ve yeraltısuyu akım yönü, 2013 yağışlı dönemini temsil etmektedir.

Belirli kuyularda seviye ölçümlerinin yapıldığı 2013Haziran yağışlı dönemine göre havzada yeraltısularının akım yönü göle doğrudur. 2013-Haziran yağışlı dönem hidrojeoloji 


\section{Journal of Research in Atmospheric Science}

haritasına göre havzanın güney ve kuzeyindeki yeraltısuları gölü besler. Gölün güney batısında Çaltı tarafında yüksek debili (93 lt/sn.) sondajlar bulunur ve bu bölgede yeraltısuyu seviyesi 10-12 m civarındadır.

Havzada debisi en yüksek sondaj, DSİ tarafından Çaltı'da açılmış ve debisi 101 lt/sn olan DSİ-47215 kuyusudur. 2013 yağışlı dönemde aynı sondajda ölçülen debi 93 lt/sn'dir. Aynı kuyunun açıldığı dönemdeki statik seviyesi $10 \mathrm{~m}$ iken, ilgili dönemdeki statik seviyesi 12 m'dir. Yukarı Yenice civarında yeraltısuyu seviyesi 5.5 m, Sazköy'de 17 m, Başmakçı'da 28 m ölçülmüştür (Tablo 1). Havzanın kuzey kısmında drenaj sistemi iyi gelişmiştir. Havzanın kuzeyinde Evciler civarına düşen yağışlar drenaj sistemi çok iyi gelişmiş olmasına rağmen göle ulaşamazlar. Gölün kuzeyinde yağışlar yeraltısuyunu beslerken, batısında yeraltısuyunu beslemekle birlikte yoğun yağış döneminde Hisaralan civarında başlayan iyi gelişmiş drenaj sistemi ile göle kadar ulaşır. Gölün güneyindeki karstik birimlerin kırık-çatlak sistemleri normal yağışların yeraltına süzülmesine neden olurken, yoğun yağışlar yeraltısuyu ile birlikte iyi gelişmiş drenaj sistemi ile yüzey akışı şeklinde doğrudan gölü besler.

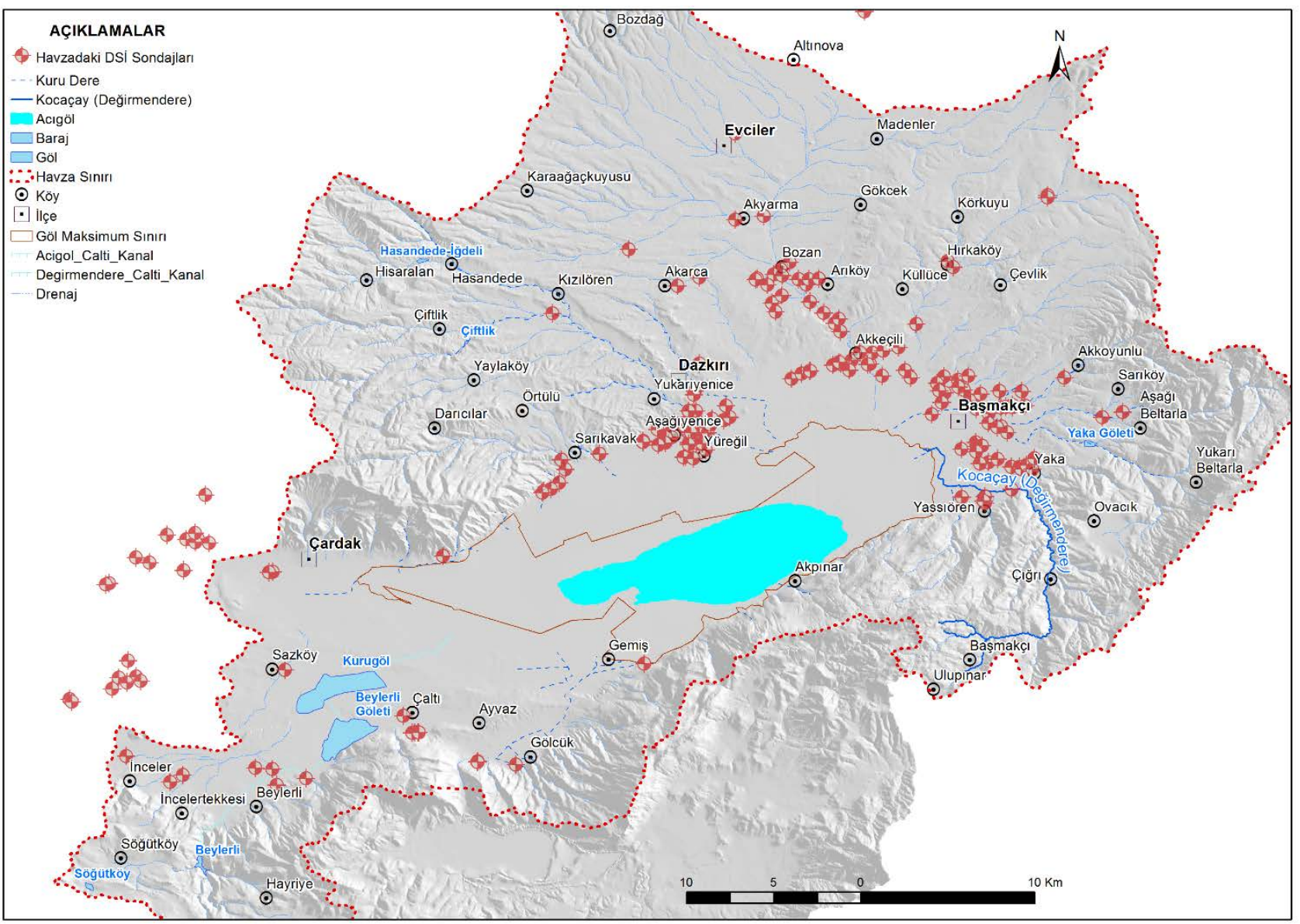

Şekil 5 Acıgöl Havzasında DSİ tarafından açılmış sondajların konumları.

Tablo 1 Yeraltısuyu seviyesi ölçülen kuyularda su seviyesi (m).

\begin{tabular}{|c|c|c|c|c|c|c|c|}
\hline Kodu & Dönemi & Enlem & Boylam & Kuyu-Sondaj & Yerleşim & Statik Seviye & Tarih \\
\hline YAS-Y-1 & Yağışı & 38,00169 & 29,89264 & DSI-55890 & Akarca & 60 & 21.06.2013 \\
\hline YAS-Y-2 & Yağışı & 37,736683 & 29,723688 & DSI-47215 & Çaltı & 12 & 23.06.2013 \\
\hline YAS-Y-3 & Yağışıı & 37,90458 & 30,02809 & DSI-46084 & Başmakçı & 28 & 23.06.2013 \\
\hline YAS-Y-4 & Yağışlı & 38,01955 & 29,77412 & Karaağaç Tulumbası & Karaağaç & 3 & 20.06.2012 \\
\hline YAS-Y-5 & Yağışıı & 37,91506 & 29,73025 & Yaylaköy Keson Kuyu & Yaylaköy & 5 & 20.06.2012 \\
\hline YAS-Y-6 & Yağışı & 37,971734 & 29,865659 & Akyarma Sondaj & Akyarma & 10 & 21.06.2012 \\
\hline YAS-Y-7 & Yağışıı & 37,90854 & 29,85327 & Yenice Kuyu & Y.Yenice & 5,5 & 21.06.2013 \\
\hline YAS-Y-8 & Yağışıı & 37,868313 & 29,866684 & Alkim-Kurutma-Sondaj & Yüreğil & 37 & 17.06 .2013 \\
\hline YAS-Y-9 & Yağışı & 37,76659 & 29,64842 & Sazköy & Sazköy & 17 & 24.06 .2013 \\
\hline YAS-Y-10 & Yağışıı & 37,7149 & 29,605189 & DSi-50497 & İnceler & 30 & 23.06 .2013 \\
\hline YAS-K-1 & Kurak & 37,88567 & 29,87265 & DSI-55754 & Yüreğil & 19,7 & 12.10.2011 \\
\hline YAS-K-2 & Kurak & 37,89103 & 29,87169 & DSI-56419 & Yüreğil & 22,1 & 12.10.2011 \\
\hline YAS-K-4 & Kurak & 37,87894 & 29,86799 & İller Bankası Kuyusu (Yüreğil İçme Suyu Kuyusu) & Yüreğil & 16 & 12.10.2011 \\
\hline
\end{tabular}




\subsection{Acıgöl Havzasında Yeraltısuyu Debi Haritası}

Havzadaki yeraltısuyunun debi dağılım haritası DSİ tarafindan açılmış derin sondajlara ait debi verilerinden üretilmiştir (Şekil 6). Havzadaki derin sondaj debileri $0.5 \mathrm{lt} / \mathrm{sn}$ ile 101 lt/sn arasında değişir. Havzada yüksek debili sular güneyde Acıgöl Fayı, kuzeyde Maymundağı-Dazkırı Fayı civarındadır. Hidrojeolojik karakteristiğe bağlı olarak yeraltısuyunun yüksek debili olduğu birimler ise hidrojeolojik olarak erimeli çatlaklı kaya ortam akiferleridir. Erimeli çatlaklı kaya ortam akifer niteliğine sahip birimler havzanın güneyinde yeraldığından, buna bağlı olarak en yüksek debili sular da havzanın güneyindedir.

Havzanın güneyinde yüksek debili sular Beylerli Göleti’nin güney-güney doğusunda Çaltt-Ayvaz-GölcükBeylerli yerleşimleri arasında kalan bölgede ve Gemiş civarındadır. Gemiş civarındaki yeraltısuyunun debisi 90.6 lt/sn iken Çaltı-Gölcük civarında 85-101 lt/sn arasında değişir. Acıgöl fayına yakın konumdaki Yassı̈ren-Yaka-Başmakçı civarındaki yeraltısularında debi 58-63 lt/sn, Başmakçı ilçe merkezi etrafinda debi 12-42 lt/sn arasındadır.

Erimeli çatlaklı kaya ortam akifer niteliği gölün kuzeyinde Sarıkavak civarında (Sarıkavak-Örtülü arası) görüldüğünden bu bölgedeki yeraltısularında da debi yüksektir. Sarıkavak civarındaki yeraltısularında debi 41-63 lt/sn arasında değişir. Havzanın kuzeyinde MaymundağıDazkırı fayına bağlı olarak yüksek debili yeraltısuları Sarıkavak ve Akkeçili başta olmak üzere Yukarı Yenice, Aşağı Yenice'dedir. Debi, Yukarı Yenice'de 36.2-54.3lt/sn, Aşağı
Yenice’de 22-73 lt/sn, Akkeçili'de 20-65 lt/sn, Yüreğil civarında ise $20-51 \mathrm{lt} / \mathrm{sn}$ arasında değişir.

Havzanın güneyinde akifüj ortamda açılmış derin sondaj bulunmamaktadır. Havzanın doğusunda ise Akkoyunlu ile Aşağı Beltarla arasında akifüj ortamda açılmış üç derin sondaj bulunur. $\mathrm{Bu}$ ortamdaki yeraltısuyu debisi 12 ile $21 \mathrm{lt} / \mathrm{sn}$ arasında değişim gösterir (DSİ-54949:12 lt/sn, DSİ46184:21/sn, DSİ-37199: 21 lt/sn). Debinin en düşük olduğu yeraltısuları ise havzanın kuzey kesimlerindedir.

\section{Sonuç ve Öneriler}

Güncel yeraltısuyu haritalarının üretimi, iklim değişimine bağlı olarak su kaynaklarının yönetimi ve planlamasında kritik öneme sahiptir. Güncel yeraltısuyu haritaları aynı zamanda detaylı ve doğru su bütçe yapılmasına olanak sağlar. Sürdürülebilir havza yönetimi için de yeraltısuyu haritalarının sürekli güncellenmesi gerekir.

Endüstriyel tuzlu göl barındıran havzalarda, gölün sürdürülebilirliğinde gölü besleyen bileșenlerin ortaya konmasında yeraltısularının havzadaki akış yönü ve gölü besleme durumları önemli hale gelir.

Aynı şekilde, içerisinde endüstriyel üretimin gerçekleştiği tuzlu göl barındıran havzalarda tarımcılık faaliyetlerinin gerçekleştirilmesi durumunda, tarım alanlarındaki aşırı su çekiminden kaynaklanabilecek tatl1-tuzlu su girişimleri, tuzlu göl suyunun tarım alanlarındaki tarımda kullanılabilir suları olumsuz etkilemesi söz konusu olabilir.

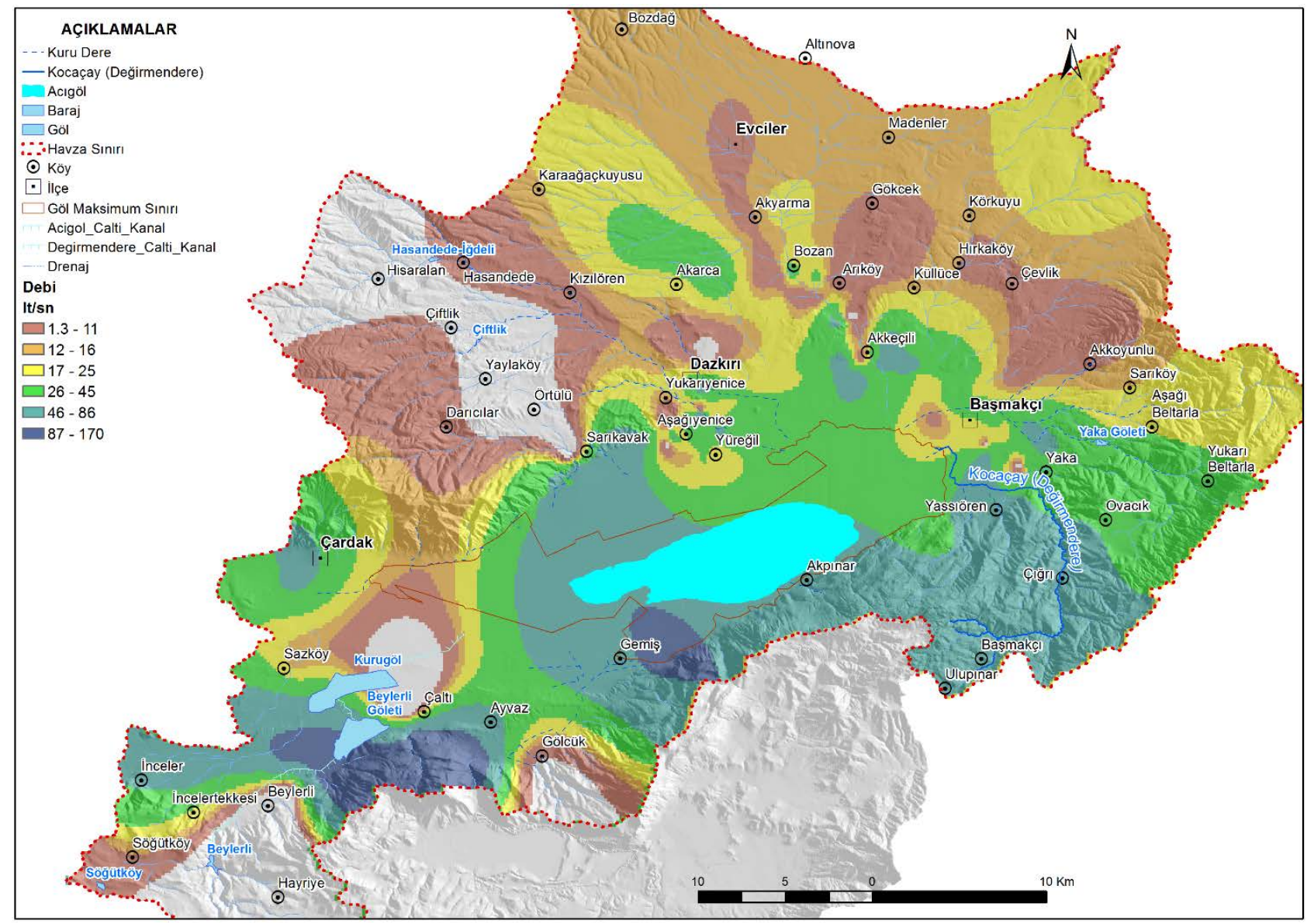

Şekil 6 Acıgöl Havzası yeraltısuyu debi haritası. 
Acıgöl gibi tuzlu bir gölün havzada varlığı göz önünde bulundurulduğunda, kuraklık dönemlerinde göl etrafindaki tarım alanlarında sulama amaçlı aşırı su çekimi, havzadaki su tablasının aşırı düşmesine ve buna bağlı olarak normal şartlarda gölü besleyen yeraltısularının tuzlu göl suyu tarafından beslenmesine dolayısıyla tuzlu-tatlı su girişiminin oluşmasına neden olabilir. $\mathrm{Bu}$ tür olumsuzlukların önüne geçilmesinde sürekli olarak yeraltısuyu seviyesinin havza bazında izlenmesi önemlidir.

Farklı nedenlerle havzanın tamamında eş zamanlı ölçüm yapılamaması durumunda, temsili seçilen kuyularda eş zamanlı ölçümle belirli bir dönem için yeraltısuyu seviye haritası elde edilerek, yeraltısuyu-göl beslenimi izlenebilir. Havzadaki yeraltısuyu iklim, yağışl1-kurak mevsim döngüsü, insani kullanım vb. birçok faktörden etkilendiğinden yeraltısuyu seviyesi bu tür havzalarda sürekli izlenmelidir. Arazi koşullarındaki yeraltısuyu seviye ve debi ölçüm değerlerinin alansal dağılımlarını gösteren haritaların üretilmesinde CBS hızlı ve güvenilir bir araçtır.

Belirli bir dönem ve temsili ölçümle belirlenen yeraltısuyu haritasına göre $1594 \mathrm{~km}^{2}$ 'lik alana sahip Acıgöl Havzasında yeraltısuyu gölü besler. Alüvyon, karstik yapılı ve bol çatlaklı birimler, çakıl-kumtaşı, çamur taşı ve konglomera birimlerinden yeraltısuyu alınmaktadır. Havzadaki derin sondaj verilerine göre yeraltısuyu debisi 0.5 ile $101 \mathrm{lt} / \mathrm{sn}$ arasında değişir. Debinin yüksek olduğu yeraltısuları, havzanın kuzeyini ve güneyini sınırlayan faylar civarındadir.

\section{Teşekkür}

Bu çalışma, TUBİTAK-110Y255 ve PAÜ BAP 2008FBE-023 projeleri tarafindan desteklenen Dr. Muhittin KARAMAN'a (2017) ait doktora tezinden üretilmiştir.

\section{Kaynaklar}

Akın, T. (2012). Beylerli jeotermal sahasının (ÇardakDenizli) hidrojeokimyasal incelenmesi. (Yüksek Lisans), Pamukkale Üniversitesi Fen Bilimleri Enstitüsü, Jeoloji Mühendisliği Anabilim Dalı, Denizli.

Aksever, F. (2012). Yeraltısuyu Bilançosu Nedir?. SDUGEO, 3(1), 37-43.

Alçiçek, M. C., Ten Veen, J. H., ve Özkul, M. (2006). Neotectonic development of the Çameli basin, southwestern Anatolia, Turkey. Geological Society, London, Special Publications, 260(1), 591-611.

Alçiçek, M. C. (2007). Tectonic development of an orogentop rift recorded by its terrestrial sedimentation pattern: The neogene Esen Basin of southwestern Anatolia, Turkey. Sedimentary Geology, 200(1-2), 117-140.

Alcicek, H. (2009). Late Miocene nonmarine sedimentation and formation of magnesites in the Acigol Basin, southwestern Anatolia, Turkey. Sedimentary Geology, 219(1-4), 115-135.

Arslan, H., Demir, Y. (2011). Bafra Ovasında Deniz Suyu Girişiminin Yeralti Suyu Kalitesi Üzerine Etkisi. Anadolu Tarım Bilimleri Dergisi, 26(2), 136-144.

Aydın vd. (2013). Sulak Alan Hidrolojisi. Meriç, B.T., ve Çağırankaya, S., (Ed.) Sulak Alanlar. (S. 41-66) içinde. url:http://www.turkiyesulakalanlari.com/wpcontent/ uploads/sulak-alanlar-kitabı-baskı-onay1-için.pdf

Balci, V. (1987). 1/100000 ölçekli Türkiye Jeoloji Haritaları. Afyon-L24, Afyon-L25 paftalart. M. T. A. Yayınları. Ankara.

Bilgin, Z. R., Karaman, T., Öztürk, Z., Şen, M. A., ve Demirci, A. R. (1990). Yeşilova-Acıgöl civarının jeolojisi. MTA Raporu, Ankara.

Collins, A. S., ve Robertson, A. H. (1999). Evolution of the Lycian Allochthon, western Turkey, as a northfacing Late Palaeozoic to Mesozoic rift and passive continental margin. Geological Journal, 34(12), 107138.

Çağırankaya, S., e Köylüoğlu, F., (2013). Sulak Alan Kavramı, Sulak Alan Nedir? Sulak Alan Sınıflandırması. Meriç, B.T.,e Çağırankaya, S., (ed.) Sulak Alanlar. (s. 7-38)içinde. http://www.turkiyesulakalanlari.com/wpcontent/upl oads/sulak-alanlar-kitabı-baskı-onayı-için.pdf

Çakaroz, D., Özelkan, E. \& Karaman, M. (2020). Sulak Alanlarda Uzaktan Algılama ile Belirlenen Zamansal Değişime Kuraklığın Etkisinin İncelenmesi: Umurbey Deltası (Çanakkale) Örneği. Avrupa Bilim ve Teknoloji Dergisi, (20), 898-916.

Davraz, A., Balın, D. (2015). Çöl (Haydarlı/Afyon) Ovasının Hidrojeolojik ve Hidrojeokimyasal Değerlendirilmesi. Afyon Kocatepe University Journal of Science \& Engineering, 15(3).

Ersoy, Ş. (1989). Fethiye (Muğla)-Gölhisar (Burdur) arasında Güney Dağı ile Kelebekli Dağ ve dolaylarının jeolojisi. (Doktora Doktora Tezi), İstanbul Üniversitesi Fen Bilimi Enstitüsü, Jeoloji Mühendisliği Anabilim Dalı, İstanbul.

Ersoy, Ş. (1990). Batı Toros (Likya) naplarının yapısal öğelerinin ve evriminin analizi. TBMMO. Jeoloji Mühendisliği Dergisi, 37, 5-16.

Essink, G.H.P.O. 2001. Improving fresh groundwater supply-problems and solutions,Ocean \& Coastal Management Volume 44, Issues 5-6 , 2001, Pages 429-449.

Franke, R. 1982. Smooth Interpolation of Scattered Data by Local Thin Plate Splines. Computer and Mathematics with Applications. Vol. 8. No. 4. pp. 273-281. Great Britain.

Göktaş, F., Çakmakoğlu, A., Tarı, E., Sütçü, Y., ve Sarıkaya, H. (1989). Çivril-Çardak arasının jeolojisi. Maden Tetkik Arama, Ankara, Türkiye, 8701.

Gündoğan, İ., Mordoğan, H., ve Helvac1, C. (1995). Türkiye'deki Acı Güllerden Sodyum Sülfat Üretimi. Endüstriyel Hammaddeler Sempozyumu, İzmir, Türkiye, 21-22.

Hacısalihoğlu, S., ve Karaer, F. (2018). Göllerde su bütçesi hesaplaması: Uluabat Gölü örneği. Toprak Su Dergisi, 7(2), 21-27.

Helvaci, C., Alcicek, M. C., Gundogan, I., ve Gemici, U. (2013). Tectonosedimentary development and palaeoenvironmental changes in the Acigol shallowperennial playa-lake basin, SW Anatolia, Turkey. Turkish Journal of Earth Sciences, 22(2), 173-190.

Hutchinson, M. F. (1988). Calculation of hydrologically sound digital elevation models. In Proceedings of the Third International Symposium on data handling

Karaman, M., Budakoglu, M., Avci, Z. D. U., Ozelkan, E., Bulbul, A., Civas, M., \& Tasdelen, S. (2015). 


\section{Journal of Research in Atmospheric Science}

Determination of seasonal changes in wetlands using CHRIS/Proba Hyperspectral satellite images: A case study from Acigöl (Denizli), Turkey. Journal of environmental biology, 36(1), 73.

Karaman, M., Özelkan, E. (2022). Comparative assessment of remote sensing-based water dynamic in a dam lake using a combination of Sentinel-2 data and digital elevation model. Environmental Monitoring and Assessment, 194(2), 1-20.

Kazancı, N., Özkul, M., Alçiçek, M. C., ve Karadenizli, L. (2006). Acıgöl Grabenindeki Geç Kuvaterner Yaşlı Havza Kenarı Tortullarının Fasiyes Özellikleri ve Göl Seviyesi Değişimi Açısından Yorumlanması, 59. Türkiye Jeoloji Kurultayl, Ankara.

Koralay, D. B. (2014). Organic geochemical and isotopic (C and $\mathrm{N}$ ) characterization of carbonaceous rocks of the Denizli Area, Western Turkey. Journal of Petroleum Science and Engineering, 116, 90-102.

Korkanç, S. Y. (2004). Sulak Alanların Havza Sistemi İçindeki Yeri. Journal of Bartin Faculty of Forestry, 6(6), 117-126

Marsh, W. (1991). Wetlands, Habitat and Land Use Planning, Environmental Applications, 2nd Editions, John Wiley and Sons Inc. New York, Usa

Meşhur, M., Yoldemir, O., Akpınar, M., Öztaş, Y., ve Alkan, H. (1989). Batl Toroslartn jeolojisi ve petrol olanakları raporu. Ankara.

Poisson, A. (1977). Recherches géologiques dans les Taurides occidentales (Turquie): Universite de Paris-Sud (Centre D'orsay).

Sarp, H. (1976). Etude géologique et minéralogique du cortège ophiolitique de la région située au NW de Yesilova (Burdur, Turquie). Univ. Genève Genève.

Seyitoğlu, G., ve Scott, B. C. (1996). Age of the Alaşehir graben (west Turkey) and its tectonic implications. Geological Journal, 31(1), 1-11.

Şenel, M., Selçuk, H., Bilgin, Z., Şen, A., Karaman, T., Dinçer, M., ve diğ. (1989) Çameli (Denizli)-Yeşilova (Burdur)-Elmalı (Antalya) ve Dolayının Jeolojisi.

Şenel, M. (1997a). 1/100000 ölçekli Türkiye jeoloji haritaları, Denizli-M23 paftası. M. T. A. Yayınları. Ankara.

Şenel, M. (1997b). 1/100000 ölçekli Türkiye jeoloji haritaları, Isparta M24 paftası. M. T. A. Yayınları. Ankara.

Şentürk, M. (2003). Acıgöl ve Burdur Gölleri Arasındaki Bölgenin Sismotektonik Özellikleri. Süleyman Demirel Üniversitesi Fen Bilimleri Enstitüsü, Jeoloji Mühendisliği Anabilim Dalı, Isparta.

Temiz, H., Poisson, A., Andrieux, J., ve Barka, A. (1997). Kinematics of the plio-quaternary Burdur-Dinar cross-fault system in SW Anatolia (Turkey), Annales Tectonicae, 102-113.

Toker, E. (2008). Acıgöl-Çardak (Denizli) grabeninin kuzeyindeki Tersiyer çökellerinin tektonosedimanter gelişiminin incelenmesi. (Doktora Tezi), Süleyman Demirel Üniversitesi Fen Bilimleri Enstitüsü, Jeoloji Mühendisliği Anabilim Dalı, Isparta.

Toker, E., Akkiraz, M. S., Yagmurlu, F., Akgun, F., ve Orcen, S. (2012). Sedimentary Properties of the MiddleUpper Eocene Formations in cardak, Burdur and Incesu, SW Turkey. Turkish Journal of Earth Sciences, 21(3), 335-373.

Yılmaz, M. (2010). Karapınar Çevresinde Yeraltı Suyu Seviye Değisimlerinin Yaratmış Olduğu Çevre Sorunları.
Ankara Üniversitesi Çevrebilimleri Dergisi, 2(2), 145-163. 